\title{
Efektivitas Penggunaan Portofolio pada Perkuliahan Mikrobiologi Terhadap Kemandirian dan Hasil Belajar Mahasiswa
}

\author{
Shofia Lubis ${ }^{1 *}$ Hasruddin $^{2}$ Mahmud $^{2}$ \\ ${ }^{1}$ Alumni Program Studi Pendidikan Biologi Program Pascasarjana Universitas Negeri Medan, Sumatera Utara, \\ Indonesia, * E-mail: shofialubis14@gmail.com \\ ${ }^{2}$ Program Studi Pendidikan Biologi, Program Pascasarjana, Universitas Negeri Medan
}

\begin{abstract}
This research study aimed to know the effectiveness of portfolio assessment in microbiology course on students' self-regulated and learning outcome. This research was the experimental research of the pretes-posttest group design. The sample was 44 students of Nondik Biologi 2013. Self-regulated questionnaire and learning outcome test were used to measure selfregulated and learning outcome of students. Data were analyzed by using independent sample t-test with SPSS statistics 21 program. The results show that: (1) Students' self regulated learning that assessed by portfolio bigger than assessed by paper test $\left(\mathrm{t}_{\text {count }}=3,105, p<0,05\right)$, the average score of students' regulated learning on experimental class (score 81) > students on control class (score 76); (2) Students' learning outcome that assessed by portfolio higher than assessed by paper test $\left(\mathrm{t}_{\text {count }}=2,861\right.$, $\mathrm{p}<0,05$ ), the average score of students' learning outcome on experimental class (score 86) $>$ students on control class (score 80); (3) Effect size portofolio assessment application on students' self regulated and learning outcome is $93 \%$ dan $81 \%$, for each. This study conclude that portfolio assessment application effective on students' self regulated and learning outcome in experimental microbiology, State University of Medan.
\end{abstract}

Keyword: Portfolio assessment, microbiology, students' regulated and learning outcome.

\section{PENDAHULUAN}

Dalam dunia pendidikan, kurikulum, proses pembelajaran, dan sistem penilaian merupakan kegiatan yang terintegrasi. Sehingga ketiga hal tersebut harus dikuasai secara baik dan seimbang oleh pendidik (Surapranata, 2006). Menguasai kurikulum dan proses pembelajaran, namun lemah dalam penilaian, akan berakibat buruk bagi peserta didik sebab "nilai" adalah "nasib" baginya. Jika salah dalam menilai maka vonis yang tidak semestinya jatuh pada peserta didik. Namun jika tidak menilai apa adanya, akan memberikan gambaran yang tidak benar pada pengguna lulusan (Haribowo, 2010).

Dalam penilaian, semestinya peserta didik tidak hanya dinilai berkenaan dengan hasil belajar, namun juga meliputi proses pembelajaran. Penilaian bermakna dapat diraih jika mencakup rincian hal apa yang masih lemah dan hal apa yang sudah dikuasai peserta didik (Salma, 2008).

Realitanya, penilaian tertulis bentuk tes esai (Yastibas, 2015) masih mendominasi pelaksanaan penilaian hasil belajar. Tes esai menuntut peserta didik menunjukkan apa yang telah dikuasai, belajar semalam suntuk sebelum ujian, penuh dengan ingatan dan hafalan (Javanmard, 2012). Pelaksanaan penilaian tes tertulis terkesan hanya untuk memenuhi kewajiban formal yaitu menentukan nilai bagi peserta didik (Pranata, 2004).

Badriyah (2010) mengungkap kondisi yang sering terjadi dalam proses penilaian yaitu dimana nilai hanya diberikan dengan melihat hasil akhir saja tanpa memperhatikan proses bagaimana peserta didik memperoleh nilai tersebut. Penilaian seperti ini tentu membuat peserta didik merasa sistem penilaian dijalankan dengan tidak adil. Masalah-masalah yang muncul akibat penilaian yang tidak tepat tentu menyakiti, menurunkan motivasi personal untuk belajar sehingga berefek buruk pada hasil belajar (Javanmard, 2012). Padahal hasil belajar merupakan cerminan usaha peserta didik dan dapat dijadikan sebagai indikator keberhasilan belajar.

Berdasarkan uraian di atas maka dibutuhkan alternatif penilaian yang tidak hanya dilakukan melalui tes akan tetapi dengan berbagai cara dan aspek penilaian, 
sehingga dapat mencerminkan usaha dan kemampuan peserta didik sebenarnya dalam aspek kognitif, afektif maupun psikomotorik dengan cara yang paling objektif dan autentik (Surapranata, 2006). Penilaian semua ranah itu dapat terjadi jika peserta didik dinilai melalui berbagai dokumen yang disatukan, yaitu melalui penilaian berbasis portofolio.

Popham (1994) dalam Arifin (2010) mengemukakan bahwa penilaian portfolio merupakan penilaian atas hasil pekerjaan peserta didik dalam kurun waktu tertentu dengan metode pengumpulan informasi atau data secara sistematik dan berkesinambungan. Stiggins (1994) mengungkap fakta bahwa manfaat portofolio sangat menonjol dibandingkan penilaian tertulis sebab portofolio melibatkan peserta didik dalam menilai kemajuan dan pencapaian belajar mereka sendiri dan turut serta dalam mengembangkan tujuan belajar yang kontinyu.

Proses pembelajaran di perguruan tinggi tidak sebatas memberikan mata kuliah, materi maupun konsep-konsep penting, namun juga harus memberikan pengalaman belajar (Hamzah, 2014) dan hal tersebut dapat difasilitasi dengan penilaian portofolio. Penilaian portofolio memungkinkan adanya umpan balik karena karya yang terekam dalam file tidak hanya dikumpulkan lalu selesai begitu saja namun akan dianalisis secara kolaboratif dengan melibatkan dosen dan mahasiswa serta dapat digunakan untuk memantau perkembangan dan mendiagnosa kesulitan belajar mahasiswa.

Di perguruan tinggi, adanya sistem kredit semester (SKS) yang memfasilitasi kegiatan tatap muka dan tugas terstruktur diluar tatap muka yang harus dikerjakan mahasiswa tanpa pengawasan dosen menjadikan kemandirian belajar hal yang urgen (Pardjono, 2007). Ketika mahasiswa menghadapi tugas/kajian mandiri, tugas proyek terbuka atau pemecahan masalah, mereka dihadapkan pada sumber informasi yang berlimpah yang mungkin relevan atau tidak relevan dengan kebutuhan dan tujuan belajar. Pada kondisi seperti itu mahasiswa harus menjadi pembelajar mandiri sehingga mampu menganalisis kebutuhan, merumuskan tujuan, memilih dan menerapkan strategi penyelesaian masalah, serta menyeleksi sumber yang relevan (Sumarmo, 2010).

Pentingnya kemandirian belajar diperkuat oleh pernyataan Wongsri (2002): bahwa kemandirian belajar harus dimiliki peserta didik terutama yang mengikuti pendidikan tinggi. Namun ternyata kemandirian belajar merupakan masalah bagi sebagian mahasiswa. Berdasarkan hasil observasi yang dilakukan peneliti serta didukung hasil penelitian Pardjono (2007) masih terdapat mahasiswa dengan kemandirian belajar yang rendah.

Belajar mandiri bukan usaha untuk mengasingkan diri. Mahasiswa boleh bertanya, berdiskusi ataupun meminta penjelasan dari orang lain. Hal terpenting adalah peningkatan kemampuan dan keterampilan dalam proses belajar sehingga pada akhirnya peserta didik tidak tergantung pada orang lain dalam belajar. Kemandirian belajar meliputi kegiatan merencanakan tujuan, cara mencapai tujuan, strategi belajar, memantau perkembangan dan mengevaluasi peningkatan diri mereka (Pardjono, 2007). Oleh karena itu, perlu penilaian yang mendukung tahapan kemandirian belajar.

Penilaian portofolio sendiri cenderung melibatkan self assessment, dimana mahasiswa dapat menilai proses serta hasil belajar berdasarkan kumpulan dokumen hasil belajarnya (Wulan, 2006). Disamping itu, portofolio mempunyai karakteristik pembelajaran self-regulated. Portofolio memungkinkan mahasiswa untuk menentukan sendiri konten, tujuan dan strategi belajarnya, kemudian merekam dokumen, sehingga peran dosen hanyalah untuk membantu dan memberikan umpan balik. Itu sebabnya pengembangan portofolio mendorong mahasiswa menjadi mandiri dalam belajar (Arends, 1998).

Hamzah (2014) dalam penelitian-nya mengungkapkan penilaian portofolio akan lebih tepat jika digunakan pada mata kuliah yang memiliki banyak tagihan tugas dan menuntut kemandirian dalam belajar. Maka penerapan penilaian portofolio dengan 
acuan kriteria sangat tepat diguna-kan pada matakuliah mikrobiologi. Pe-nilaian portofolio paling tepat digunakan ketika pembelajaran dapat didemons-trasikan melalui sebuah produk.

Mikrobiologi merupakan mata kuliah wajib semester enam di Prodi Biologi Universitas Negeri Medan. Mata kuliah ini mengkaji sejarah perkembangan mikrobiologi, mikroorganisme dan karakteristiknya, peran mikroorganisme dalam kehidupan, metabolisme dan pertumbuhan mikrobia, aktivitas biokimia bakteri serta fermentasi makanan. Setelah mengikuti matakuliah ini mahasiswa diharapkan memiliki wawasan pengetahuan tentang kajian mikrobiologi dan mikroorganisme serta memiliki keterampilan dalam aspek dan aktivitas yang terkait mikroorganisme.

Merujuk pernyataan di atas, maka penelitian ini bertujuan menguji efektivitas penilaian portofolio terhadap kemandirian dan hasil belajar mahasiswa.

\section{METODE}

Jenis penelitian ini adalah penelitian quasi eksperimen dengan desain pretestposttest control group design. Penelitian dilakukan selama semester genap di Prodi Biologi, Universitas Negeri Medan T.A 2015-2016. Populasi dari penelitian ini mahasiswa prodi biologi yang sedang mengikuti perkuliahan mikrobiologi. Melalui teknik cluster random sampling diperoleh sampel yaitu Nondik A 2013 sebagai kelas eksperimen dan Nondik B 2013 sebagai kelas kontrol, masing-masing berjumlah 22 mahasiswa.

Kelas eksperimen diberi perlakuan dengan penerapan penilaian portofolio, sedangkan kelas kontrol diberikan penilaian tertulis. Setelah kegiatan pembelajaran selesai, sampel penelitian diberikan postes untuk mengetahui hasil belajar kedua kelas tersebut, sehingga efektivitas perlakuan dapat terlihat. Hasil postes dianalisis dengan uji-t satu pihak untuk mengetahui penerapan penilaian mana yang lebih baik. Setelah kegiatan pembelajaran selesai, mahasiswa di wawancarai mengenai respons mereka terhadap penerapan penilaian portofolio pada perkuliahan mikrobiologi.

Untuk mengetahui pengaruh per-lakuan pada perkuliahan mikrobiologi dilakukan analisis uji-t pada taraf signifikansi 0,05 dengan program SPSS statistics 21.

\section{HASIL DAN PEMBAHASAN}

Deskripsi Data Kemandirian dan Hasil Belajar

Data kemandirian belajar mahasiswa diambil dari kelas eksperimen dan kontrol pada pertemuan terakhir dengan membagikan angket. Ringkasan data setiap indikator kemandirian belajar mahasiswa dapat dilihat pada Gambar 1.

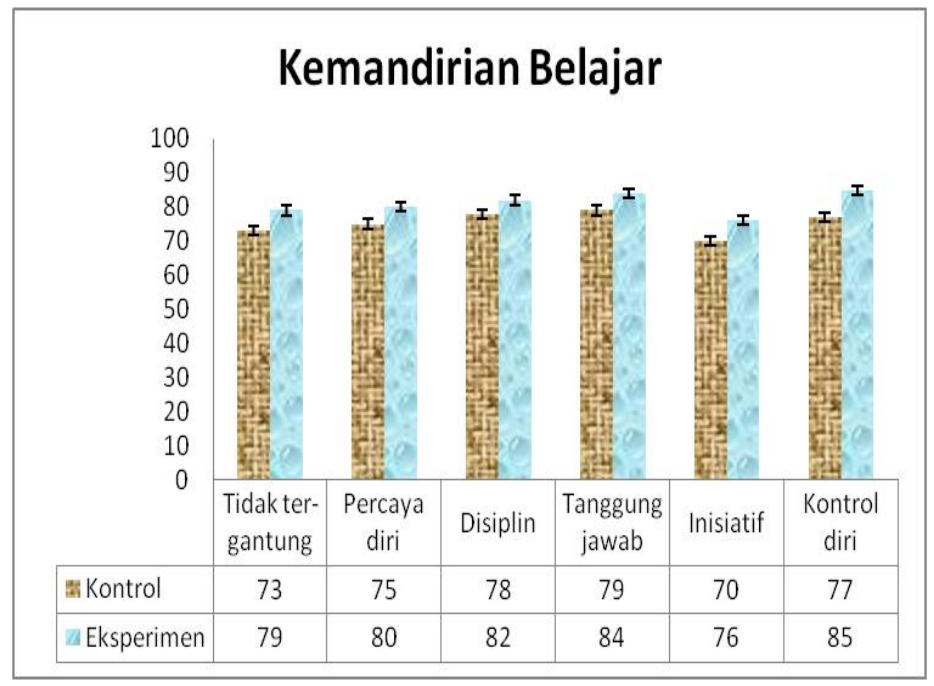

Gambar 1. Tingkat Kemandirian Belajar 
Gambar 1 menampilkan tingkat kemandirian belajar mahasiswa ditinjau dari 6 indikator kemandirian belajar. Pada kelas eksperimen indikator kontrol diri merupakan persentasi tertinggi yaitu $85 \%$ sementara pada kelas kontrol hanya meraih $77 \%$. Secara keseluruhan rata-rata nilai kemandirian belajar mahasiswa kelas eksperimen sebesar $85 \%$ dan dikategorikan sangat baik. Sementara rata-rata nilai kemandirian belajar mahasiswa kelas kontrol sebesar $76 \%$, kategori baik.

Data hasil belajar diperoleh rata-rata nilai pretes 28 dan 29 masing-masing kelas kontrol dan eksperimen. Data postes kelas eksperimen menunjukkan rata-rata 86 , nilai minimum 75 dan maksimum 99. Sedangkan postes kelas kontrol diperoleh rata-rata 80 , nilai minimum 62 dan maksimum 91. Perbedaan nilai pretes dan postes dua kelompok disajikan Gambar 2.

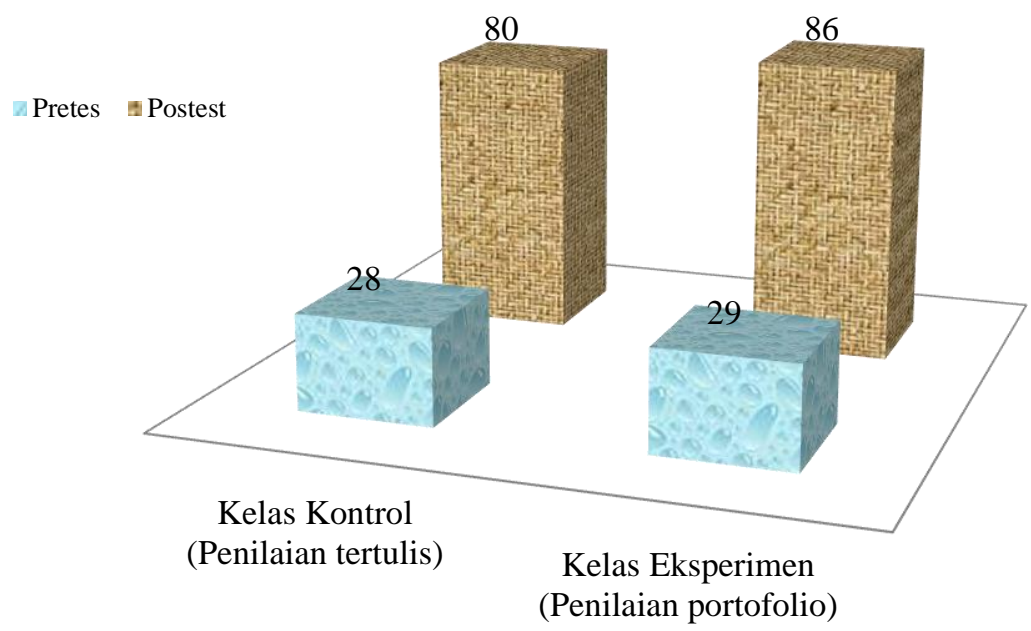

Gambar 2. Rata-Rata Hasil Belajar

Berdasarkan perhitungan dengan menggunakan data nilai pretes dan postes diperoleh indeks gain sebesar 0,80 untuk kelas eksperimen dan 0,72 untuk kelas kontrol. Interpretasi melalui kriteria indeks gain menunjukkan peningkatan hasil belajar mahasiswa pada kedua kelompok termasuk dalam kategori tinggi.

\section{Pengujian Persyaratan Analisis}

Pengujian normalitas menggunakan program SPSS statistics 21 dengan uji Kolmogorov-Smirnov pada taraf signifikan $\alpha=0,05$. Diperoleh bahwa semua kelompok data memiliki $\mathrm{p}>0.05$, menunjukkan data memiliki sebaran normal. Berdasarkan uji homogenitas diperoleh nilai Sig: $p>0,05$ sehingga dapat disimpulkan bahwa kedua kelompok data homogen.

\section{Uji Hipotesis}

Setelah dilakukan uji prasyarat, diketahui bahwa data berdistribusi normal dan bervarians homogen maka dilanjutkan dengan uji hipotesis. Hal ini dilakukan untuk mengetahui tingkat kemandirian dan hasil belajar setelah mahasiswa diberi perlakuan. Berdasarkan perhitungan t-test independen sampel diperoleh hasil perhitungan seperti pada Tabel 1 .

Tabel 1. Ringkasan Perhitungan Uji Hipotesis

\begin{tabular}{lllllc}
\hline \multicolumn{1}{c}{ Data } & Nilai Rata-rata & $\mathrm{t}_{\text {hitung }}$ & Sig: $p$ & \multicolumn{2}{c}{ Kesimpulan } \\
\hline \multirow{2}{*}{ Kemandirian belajar } & 81 & 3,105 & 0,0015 & Hipotesis I & Terima H $_{1}$ \\
& 76 & & & & \\
Postes & 86 & 2,861 & 0.0035 & Hipotesis II & Terima $\mathrm{H}_{1}$ \\
\hline
\end{tabular}


Hipotesis ke-1 dilakukan untuk mengetahui tingkat kemandirian belajar mahasiswa. Hasil perhitungan uji perbedaan nilai rata-rata kemandirian belajar kelas eksperimen dan kelas kontrol diperoleh nilai $\mathrm{p}<0,05$ dengan uji-t satu pihak pada taraf signifikansi 0,05 . Oleh karena nilai $\mathrm{p}<$ 0,05 maka $\mathrm{H}_{1}$ diterima, artinya kemandirian belajar mahasiswa yang dinilai dengan penilaian portofolio lebih besar daripada mahasiwa yang dinilai dengan penilaian tertulis.

Sebelum hipotesis ke-2 di uji maka harus dipastikan bahwa dua kelompok sampel memiliki kemampuan pengetahuan awal yang sama, hal ini diindikasikan melalui nilai pretes. Dengan uji-t dua pihak didapatkan nilai $\mathrm{p}>0.05$ sehingga disimpulkan bahwa kemampuan awal mahasiswa kelas eksperimen sama dengan kemampuan awal mahasiswa kelas kontrol sebelum diberikan perlakuan sebab nilai pretes kedua kelas tidak berbeda secara signifikan.

Selanjutnya uji-t dilakukan dengan perhitungan data nilai postes. Hasil pengujian mendapatkan hasil $\mathrm{p}<0.05$ dimana hal ini berarti $\mathrm{H}_{0}$ ditolak dan $\mathrm{H}_{1}$ diterima. Hal ini menunjukkan bahwa hasil belajar mahasiswa yang menggunakan penilaian portofolio lebih tinggi daripada mahasiswa yang menggunakan penilaian tes tertulis pada praktikum mikrobiologi prodi biologi Universitas Negeri Medan.

Uji hipotesis ke-3 menggunakan rumus sumbangan efektif. Sumbangan efektif digunakan untuk mengetahui berapa persen sumbangan perlakuan yang diberikan dalam meningkatkan skor pada kelompok eksperimen. Melalui program bantu kalkulasi, dengan memasukkan nilai ratarata kemandirian belajar, rata-rata hasil belajar, standar deviasi dan ukuran sampel pada kedua kelompok diperoleh sumbangan efektif pemberian perlakuan penilaian portofolio dalam meningkatkan skor kemandirian dan hasil belajar masingmasing sebesar $93 \%$ dan $81 \%$.

\section{PEMBAHASAN}

Penilaian portofolio ialah penilaian berkelanjutan berdasarkan kumpulan informasi yang menunjukkan hasil belajar selama satu semester. Pemberian tugas portofolio yang meliputi laporan praktikum, presentasi hasil praktikum, jurnal mini riset, poster kunjungan adalah upaya dalam mengoptimalkan kemandirian dan hasil belajar. Portofolio akan efektif jika penilaiannya menuntut mahasiswa menunjukkan kemampuan nyata serta menggambarkan pengembangan aspek pengetahuan, sikap dan keterampilan pada taraf yang tinggi (Surapranata, 2006).

\section{Kemandiran Belajar}

Kemandirian belajar dalam penelitian ini diukur dengan angket yang meliputi aspek (persentasi perolehan): Ketidaktergantungan terhadap orang lain (79\%); (2) Memiliki kepercayaan diri (80\%); (3) Berperilaku disiplin (82\%); (4) Memiliki rasa tanggung jawab (84\%); (5) Berperilaku berdasarkan inisiatif sendiri (76\%); (6) Melakukan kontrol diri (85\%). Tingkat kemandirian belajar mahasiswa dalam praktikum mikrobiologi dengan penilaian portofolio tergolong sangat baik.

Berdasarkan hasil temuan di atas, penilaian portofolio ditengarai mampu menumbuhkembangkan kemandirian belajar mahasiswa. Sejalan dengan yang dikemukakan Gunay (2014): penilaian portofolio memfasilitasi kemandirian belajar karena mahasiswa menjadi sangat mandiri ketika mereka "dipaksa" untuk merencanakan kegiatan belajar, memonitor kemajuan, mengevaluasi keberhasilan usaha belajar mereka. Mahasiswa yang dinilai dengan penilaian portofolio memiliki indikator kemandiran belajar berupa kontrol diri yang baik, hal ini dapat dilihat pada sikap yakin akan aktifitas belajar yang berdampak pada dirinya, sikap senantiasa mengevaluasi hasil belajar dan sikap mencermati kenaikan dan penurunan hasil belajar yang diperoleh. Mahasiswa juga dapat mengelola waktu dengan baik, dapat membedakan mana aktivitas yang penting, mana yang mendesak dan mana yang memerlukan tindakan segera. 
Penilaian portofolio juga mendukung indikator disiplin dalam kemandiran belajar, mahasiswa kelas eksperimen meraih persentasi disiplin sebesar $82 \%$ sementara kelas kontrol hanya $78 \%$. Keberhasilan mendisiplinkan diri tentunya memerlukan latihan berkesinambungan. Latihan dimulai dengan membiasakan diri mengerjakan tugas sebelum deadline. Indikator yang lain adalah percaya diri, hal ini tercermin dari sikap mahasiswa yang memiliki keyakinan bahwa ia mampu mengatasi masalah atau hambatan yang dihadapi dalam kegiatan belajar. Mahasiswa yang percaya diri juga memiliki kemampuan menyelesaikan pekerjaan dengan sistematis, berencana, efektif, dan efisien.

Menurut Salma (2008) mahasiswa mandiri biasanya memiliki kebiasaan: (1) Tidak menunggu diarahkan orang lain, memiliki motivasi atau yang kuat serta memahami perkembangan teknologi; (2) Mampu mengatasi segala keterbatasannya; (3) Belajar kapan saja jika belajar dirasakan perlu; (4) Belajar di mana saja, tidak perlu lokasi tertentu; (5) Rasa ingin tahu yang tinggi, seandainya ada kesulitan, mampu menangani sendiri tanpa menunggu bantuan atau paling tidak berusaha sendiri terlebih dahulu sebelum ditangani oleh dosen.

\section{Hasil Belajar}

Pada awal penilaian portofolio mahasiswa diberikan skenario tagihan tugas dan pedoman penilaian portofolio sebagai acuan menyelesaikan tagihan tugas. Tugas yang terarah tentu akan memaksimalkan hasil belajar dan kompetensi dapat tercapai. Jika tugas belum mencapai hasil yang memuaskan, maka mahasiswa berkesempatan melakukan perbaikan sehingga mereka dapat mempelajari kesalahan, kekurangan, serta strategi belajarnya agar lebih efektif.

Penerapan penilaian portofolio selama proses praktikum mikrobiologi berlangsung menunjukkan pengaruh positif terhadap hasil belajar mahasiswa. Pengaruh ini ditunjukkan dengan adanya hasil dari uji peningkatan hasil belajar. Hasil belajar mahasiswa yang dinilai dengan penilaian portofolio meningkat sebesar $80 \%$ dan merupakan peningkatan yang termasuk dalam kategori tinggi. Hasil penelitian memperoleh hasil belajar mahasiswa yang dinilai dengan penilaian portofolio lebih tinggi dibandingkan dengan penilaian tertulis sebesar 8\%. Hal ini disebabkan karena penilaian portofolio tidak hanya menilai hasil belajar namun juga peduli akan proses bagaimana nilai itu bisa diperoleh.

Merujuk pada peningkatan hasil belajar, Gunay dan Bekiroglu (2014) telah melakukan penelitian untuk mengetahui dampak penilaian portofolio terhadap hasil belajar mahasiswa, diperoleh rata-rata nilai belajar kelas kontrol sebesar 66,5 sementara kelas eksperimen sebesar 83,7. Temuan ini mengindikasikan bahwa mahasiswa yang dinilai dengan penilaian portofolio mengkonstruksi lebih banyak pengetahuan dibandingkan mahasiswa yang tidak dinilai dengan portofolio.

Adanya rubrik penilaian yang jelas dalam penilaian portofolio membuat mahasiswa fokus dalam mencapai tujuan pembelajaran dan lebih menghargai penilaian karena berlangsung secara transparan. Pada saat presentasi misalnya, mahasiswa tidak saling mengandalkan tetapi bekerja sama sehingga secara merata mereka memahami materi yang disampaikan. Pada kesempatan ini terjadi interaksi yang saling membangun antar mahasiswa dalam kelompok. Masalah yang dihadapi oleh mahasiswa ketika menyelesaikan tagihan tugas dipecahkan bersama dalam diskusi kelompok. Peran peneliti sebatas membantu mengarahkan logika berfikir mahasiswa untuk sampai pada pemecahan yang benar.

Gunay (2014) telah melakukan penelitian mengenai dampak penilaian portofolio, dalam hal ini penilaian portofolio terdiri atas evaluasi diri, refleksi diri serta adanya umpan balik. Ketiga hal tersebut juga dilakukan pada penelitian ini. Adanya umpan balik yang diberikan terhadap tagihan tugas ternyata merangsang $85 \%$ mahasiswa untuk sungguh-sungguh mengerjakan tugas, tes dan revisi, implikasinya mereka selalu ingin 
menampilkan pekerjaan terbaik dalam portofolionya. Seperti yang dikemukakan Birgin (2007), penilaian portofolio memungkinkan mahasiswa menunjukkan kelebihan dan kekurangan, sehingga baik dosen maupun mahasiswa lebih mudah mengobservasi kemajuan belajarnya.

Pada akhir kegiatan praktikum, lembar refleksi diisi mahasiswa. Sebagaimana yang disampaikan Davis (2005) penilaian diri merupakan hal yang membedakan antara tugas biasa dengan portofolio, bukti dokumen bisa dirangkum dalam lembar refleksi. Mahasiswa dapat merefleksikan pengalaman belajar melalui tiga tingkatan kognitif, yaitu: dekskriptif, analitik, dan evaluatif. Lembar refleksi berisi mengenai hal-hal seperti pema-haman mereka mengenai kekurangan dan kelebihannya serta bagaimana pendapat-nya terhadap penilaian portofolio. Dapat dikatakan bahwa hal yang disampaikan mahasiswa telah dilaporkan Tubaishat (2013), bahwa secara keseluruhan mahasiswa menyukai sistem penilaian portofolio dan dengan penilaian ini mereka menghabiskan banyak waktunya untuk mencari referensi guna memastikan bahwa tujuan pembelajaran mereka tercapai.

Pada akhir pertemuan mahasiswa diwawancarai untuk mengetahui respon mereka mengenai penggunaan penilaian portofolio pada praktikum mikrobiologi. Mahasiswa ternyata belum pernah dinilai dengan menggunakan penilaian portofolio, meskipun begitu $86 \%$ mahasiswa merasa senang dengan penilaian portofolio dan berharap penilaian ini juga diterapkan pada perkuliahan lainnya. Secara umum mahasiswa memberikan tanggapan positif terhadap penggunaan penilaian portofolio pada praktikum mikrobiologi. Seperti hasil penelitian yang dilakukan oleh Gunes, Demir dan Balaban (2015), beberapa mahasiswa memang mengalami kesulitan pada tahap awal penggunaan penilaian portofolio dan cenderung bersikap negatif terhadap penilaian itu, namun seiring berjalannya proses penilaian mahasiswa merasa puas dengan sistem penilaian dan bahkan tertarik untuk meneruskan penggunaannya.

\section{SIMPULAN}

Berdasarkan hasil penelitian dapat diambil simpulan bahwa baik kemandirian maupun hasil belajar mahasiswa yang dinilai dengan penilaian portofolio lebih tinggi daripada mahasiswa yang dinilai dengan menggunakan penilaian tertulis. Oleh sebab itu penilaian portofolio efektif dalam menumbuhkembangkan kemandirian belajar dan meningkatkan hasil belajar mahasiswa pada perkuliahan mikrobiologi, Prodi Biologi, Universitas Negeri Medan.

\section{DAFTAR PUSTAKA}

Arifin, Z. 2010. Kerangka Pedoman Penilaian Portofolio. Makalah. Bandung: FIP UPI.

Badriyah, Z. 2010. Efektivitas Penilaian Portofolio Terhadap Hasil Belajar. Skripsi. Semarang: IAIN walisongo.

Birgin, O. and Baki, A. 2007. The Use of Portofolio to Assess Student's Performance. Journal of Turkish Science Education, 4 (2): 75-90.

Davis, Margery. H. dan Ponnamperuma, G. G. 2005. Portofolio Assessment. Journal of Veterinary Medical Education, 32 (3): 279284.

Gunay, A. dan Bekiroglu, F. G. 2014. Impact of Portfolio Assessment on Physics Students' Outcomes: Examination of Learning and Attitude. Eurasia Journal of Mathematics, Science \& Technology Education, 10 (6): 667-680.

Hamzah, A. 2014. Evaluasi Pembelajaran. Jakarta: PT Raja Grafindo Persada

Haribowo, H. 2000. Penilaian Portofolio. Buletin Pelangi: Peningkatan mutu pendidikan Menengah Umum.

Javanmard. Y., dan Farahani, H. 2012. Investigating Using Portfolio Assessment and Learning English Language in Qom Secondary Schools. Global Journal of Human Social Science, 12 (12): 52-60.

Pardjono. 2007. Kemandirian Belajar Mahasiswa Pendidikan Teknik Mesin Ditinjau dari Asal Sekolah, Tempat Tinggal dan Lama Studi. Cakrawala pendidikan, 1: 83-103.

Pranata, M. 2004. Portofolio: Model Penilaian Desain Berbasiskan Kons-truktivistik. Nirmana, 6 (1): 63-81.

Salma, D. 2008. Prinsip Desain Pem-belajaran. Jakarta: Kencana. 
Stiggins, R. J. 1994. Student-Centered Classroom Assesment. New York: Macmillan Publishing Company.

Sumarmo, U. 2010. Kemandirian Belajar: Apa, Mengapa, dan Bagaimana Di-kembangkan Pada Peserta Didik. Bandung: FMIPA UPI.

Surapranata, S., Hatta, M. 2006. Penilaian Portofolio: Implementasi Kurikulum 2004.Bandung: PT Remaja Rosdakarya.

Tubaishat, A. dan Lansar, A. 2013. Using Student e-Portfolios to Facilitate Learning
Objective Achievements in an OutcomeBased University. Journal of Information Technology Education, 12: 114-127.

Yastibas, A. E., dan Yastibas, G. C. 2014. The Use E-Portfolio-Based Assessment to Develop Students' Self regulated Learning In English Language Teaching. Procedia Social and Behavioral Sciences, 176 (15): 3-13. 